\title{
ROUTLEDGE HANDBOOK OF YOGA AND MEDITATION STUDIES
}

Edited by Suzanne Newcombe and Karen O'Brien-Kop

First published 2021

ISBN: 978-1-138-48486-3 (hbk)

ISBN: 978-1-351-05075-3 (ebk)

\section{7}

\section{OBSERVING YOGA}

The use of ethnography to develop yoga studies

Daniela Bevilacqua

(CC BY-NC-ND 4.0)

This project has received funding from the European Research Council (ERC) under the European Union's Horizon 2020 research and innovation programme (grant agreement No 647963 (Hatha Yoga Project)).
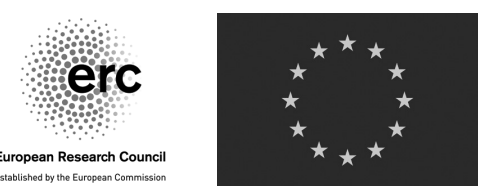


\title{
27 \\ OBSERVING YOGA \\ The use of ethnography to develop yoga studies ${ }^{1}$
}

\author{
Daniela Bevilacqua
}

\section{Introduction}

Ethnography as a method can be defined as an approach to social research based on first-hand experience. As a methodology, it intends to create an epistemology that emphasises the significance and meaning of the experiences of the group of people being studied, thereby privileging the insider's view. A researcher using ethnography employs mostly qualitative methods (Pole and Morrison 2003: 9), such as interviews (that can be non-structured, structured or casual conversation), participant observation, field notes, etc.

Participant observation can be considered as a distinctive feature of ethnography; within this method the researcher adopts a variety of positions. As Atkinson and Hammersley have noted (1994: 248), the researcher can be: a complete observer when the researcher is a member of the group being studied who conceals his/her researcher role; an observer as participant when $\mathrm{s} / \mathrm{he}$ is a member of the group being studied and the group is aware of the research activity; a participant as observer when $s /$ he is not a member of the group but is interested in participating as a means for conducting better observation; or a participant non-member of the group who is hidden from view while observing. These typologies work differently according to other variables (Atkinson and Hammersley 1994: 249): what is known about the research and by whom; in which activities the researcher did and did not engage, and how this locates the researcher in relation to the various conceptions of category and group membership used by participants; what the orientation of the researcher is and how completely s/he consciously adopts the orientation of insider or outsider; and so on. These variables, which influence the collection of data and therefore their analysis, should be clear to the researcher while writing (through an attentive reflexive examination), and to the reader who, taking them into consideration, can better understand, contextualise and evaluate the background and the content of the work.

The final product of the ethnographic research should incorporate the views of the participants (emic perspective) as well as the analysis of the researcher (etic perspective). This portrait can open up understanding and interpretation that goes beyond what quantitative research can do, sometimes challenging or highlighting notions that are taken for granted. For this reason, although ethnography was pioneered in the biological, social and cultural branches of anthropology, it has also become popular among those disciplines that decide to observe social practices and interactions of cultural groups of people, such as social sciences, sociology, religious studies, history and, of course, yoga studies. 


\section{Ethnography as a method within yoga studies}

Given the diffusion of yoga and meditation all over the world, and the constantly increasing number of people practicing one of the various typologies of yoga, it was inevitable that scholars from various disciplines and branches of knowledge would eventually address these practices and their resulting transcultural/transnational communities. ${ }^{2}$ However, such scholarly interests only properly developed after Elizabeth De Michelis (2004) published her study on 'Modern Yoga' and its various sub-categories, providing the input and the general theoretical substratum needed for the development of yoga studies.

The presence of yoga studies as a new field of academic inquiry 'shows how the emergence and diversity of today's postural yoga provides rich source material for understanding the process of cultural diffusion and knowledge transfer' (Hauser 2013b: 1). Indeed, yoga has been evaluated for its transnational aspect, since it is taught and practised at a global level, and for its transcultural aspect, since practices and theories are negotiated and adjusted according to various, local contexts. Looking at yoga in relation to these two aspects

provides useful terms and descriptive categories that help one grasp more fully the mutual influence of the varying schools of yoga, the competing ways in which yoga has been circulated, and the twists and turns in yoga's overall orientation [...] The concept of transcultural flows also provides a frame of reference that can locate and connect individual research results to larger perspectives, statements, representations, and developments.

(Hauser 2013b: 23)

These two aspects also correspond to a transdisciplinary approach that many scholars have adopted: in dealing with modern yoga, scholars engage in different methods, and one of these is the ethnographic. This is evident when we consider the scope of some recent edited volumes published within the field of yoga studies.

In 2005 Knut A. Jacobsen published Theory and Practice of Yoga, with the purpose of evaluating yoga 'as a historical and pluralistic phenomenon flourishing in a variety of religious and philosophic contexts' (2005: 3). Although the majority of the articles are based on textual or historical evidence, a few show an interest in the contemporary context and are extensively based on fieldwork data. Ramdas Lamb, for example, provides information about the practice of Rāmānandī ascetics (323-330), while Tracy Pintchman (355-362) points to female yogic practices based on kartik vrat (vows during the Indian month of Kartik) and $p \bar{u} j \bar{a}$.

In 2008, Mark Singleton and Jayne Byrne edited Yoga in the Modern World, which offers 'a range of perspectives on yoga's contemporary manifestations' with contributions that 'span a number of disciplines in the humanities, including anthropology, philosophy, studies in religion and Asian studies, offering a range of entry points to the issues involved in the study of the subject' (2008: 1).

On a similar track and using a comparable range of specialists, in 2013 Singleton and Goldberg presented Gurus of Modern Yoga, which explored the role that modern international gurus have had in the formation of practices and discourses of modern, transnational yoga in India and elsewhere. Ethnography was one of the methods used by contributors to explore this subject in the volume.

In the same year, Beatrix Hauser edited Yoga Travelling, resulting from a 2009 meeting held in Heidelberg University in which an interdisciplinary group of scholars from Europe and the United States discussed 'the specifics of present-day yoga and its global appeal' (2013b: 5). 
The research questions behind this meeting are similar to those present in several studies that manifest an ethnographic approach:

For what reasons do people engage in yoga classes? How did particular social environments shape the practice of yoga and how did these situated practices in turn influence the perception and experience of body and self? In what ways has the spread of yoga served as a social and cultural incentive that inspires and reorients general ways of thinking about health and human well-being?

(Hauser 2013b: 5)

Taking these questions as starting point, this chapter initially provides an outline of the studies in which ethnography is 'naturally' embedded so as to demonstrate how it emerges as a preferred method for yoga studies. Following this, the chapter focuses on the ethnographic work that I have been conducting since 2015 among ascetic practitioners of yoga in India. I provide an analysis of data from my own fieldwork, demonstrating how ethnographic work, used together with other methods, can help in understanding not only present situations, but also their historical developments. In conclusion, the chapter argues for the importance of the ethnographic method itself in order to understand contemporary yoga and meditation practices.

\section{Dealing with yoga and meditation from an ethnographic perspective}

Ethnography traditionally required spending long periods of time in the field. However, much contemporary ethnography, which can be sided or multi-sided, has now moved 'out from the single sites and local situations of conventional ethnographic research designs to examine the circulation of cultural meanings, objects, and identities in diffuse time-space' (Marcus 1995: 96). Many studies of contemporary yoga movements incorporate an element of ethnographic fieldwork to explore the significance and meaning of the activity to practitioners.

To give a few examples of authors who have conducted single-sided fieldworks in a particular location: Suzanne Hasselle-Newcombe (2005) supplemented a quantitative case study by using participant observation among British practitioners of the Iyengar Method of Yoga; Verena Schnäbele (2010) combined ethnographic observation with in-depth interviews of thirty-four individuals representative of the major styles of yoga regularly practised in group classes in Hamburg. Other recent studies on yoga incorporating fieldwork methods include Mans Broo (2012), who analysed Finnish practitioners and their relationship with practice; Laura Mandelbaum who, in her research conducted tegether with Sara Strauss (2013), worked on Ashtanga practitioners in Toronto; and Theodora Wildcroft's (2020) exploration of the lived experience of contemporary, transnational yoga practices in Britain.

Other studies adopt a multi-sited ethnography in order to "follow the paths of transnational cultural flows of ideas, practices and people' (Strauss 2005: xix). Sara Strauss did her fieldwork among practitioners attending classes at the Sivananda Ashram in Rishikesh, India, and in their country (i.e. Germany and USA) to explore how they integrated yoga in their everyday life and, consequently, transformed it and its practices.Veronique Altglas highlights that the 'advantage of cross-national approaches is that they avoid generalizing what may be specific to a case study in one location' (2014: 21). For her research, between 1999 and 2005 she conducted participant observation and collected eighty non-directive interviews with the leaders and members of Siddha Yoga and Sivananda Centres in London and Paris, and semi-structured interviews with those involved in the management of religious diversity in both countries (2014: 18-19). Benjamin Smith (2004) conducted ethnographic research on the practice of Ashtanga Vinyasa 
Yoga among western practitioners in Australia, India and other locations to reflect on the embodied experience of asana practice. Klas Nevrin (2008) conducted ethnographic research with people doing yoga in environments inspired by Krishnamacharya, primarily in Sweden but also in India. (See also Ciołkosz, Chapter 33 in this volume). Another interesting multi-sided research was conducted by Andrea Jain (2014) on the propagation of prekșā dhyāna, a yoga and meditation practice established by the Jain Terapānth group, in Rajasthan and Houston.

Pagis Michal (2010) collected data through two years of participant observation of vipassana meditation practices in Israel and the United States. As Gustaaf Houtman argues in his study on Buddhism in Burma, the location of a fieldwork can produce remarkable differences in findings. He stresses the variations that he found while researching meditation in a monastery and in a meditation centre: 'While in the monastery knowledge can be received in a social context and transmitted between people, in the meditation centre knowledge is not conceived in its "received" form but only as an experiential knowledge derived from lengthy private dedicated "work"' (Houtman 1990: 156). Those meditating in the centre would not have the time or the inclination to talk to the anthropologist, since social pleasantries are a distraction from meditation. Houtman admits that neither his personal experience nor his anthropological training had equipped him to approach such intrinsically anti-social activity. This clearly exemplifies the nature of fieldwork: a 'place' can be a source of information but can also be a black hole for the researcher, who has to face circumstances and events that cannot be anticipated in advance and may depend on his/her interaction and involvement in the field. This also explains why, in a successful fieldwork, participant observation can be a fundamental tool to collect original, qualitative data.

Strauss argues that, for her, "participation in yoga classes was absolutely essential, not only to gaining credibility in the eyes of the community, but also to the personal bodily understanding of the transformations these practices make possible' (2005: 60). Joanna Cook (2010) even decided to become ordained and to practise meditation in order to understand what it is like to be a monastic and the way in which monastic identity is formed through ascetic practice. In so doing, she also wanted to experience the effects of religious practice on her own feelings and sense of self. She combined in-depth and long-term participant observation with formalised research methods: she conducted surveys and questionnaires, conducted formal and informal interviews, collected life-histories and documented rituals, but she also undertook regular intensive meditation retreats to cut attachment to a sense of self. As she argues, "intensive embodied practice of this sort provided a way of understanding abstract concepts of "truth" in the field while remaining "true" to the roles of mae chee (nun) and meditator adopted in the field' (2010: 20-22).

Scholars might, indeed, become 'insider going outsider, going native in reverse' (Pearson 2001: 57), which means a practitioner of yoga may decide to join the academy to study topics related to yoga and then take this new knowledge and insights back into their practice communities (see Singleton and Larios, Chapter 4 in this volume) As we will see in the final part of this chapter, such a position could be 'dangerous' if not supported by an attentive, reflexive approach.

\section{Data from fieldworks}

In recent decades, scholars involved in yoga studies have tried to understand why people engage in yoga, also focusing their attention on the premises and the consequences of that. A general conclusion of these studies is that modern lifestyles have created conditions in which people are overwhelmed by stress and therefore are looking for balancing strategies. Since yoga 'is praised as a relaxing, healthy body technique' it has become increasingly popular (Schnäbele 2013: 143). 
Practitioners are part of global health ideas according to which one has to keep oneself fit and free of physical and mental diseases thorough emotional balance, mental flexibility and self-care (Hauser 2013a: 111). That is why, as Nevrin (2008: 119) highlights, the experiences of the body are 'essential [...] to understand the effects of yoga practice and to explain its increasing popularity'. The work of Ann Koch is exemplary in that respect: most of her informants reported that they started yoga because of back problems. Practicing yoga gave them more flexibility and mobility, and some started taking more care of their body, changing their body perception and, in general, their mode of paying attention, which deeply influenced their everyday life (2013: 236). Schnäbele (2010) considers how and in what ways the awareness of the body is shaped in and by yoga practice in contemporary Germany. She claims that in contemporary yoga practice the human body is generally structured by the experience of limits (of personal strength and flexibility) and by 'an inside versus outside perspective of the body' that would result in a 'useful body', a body that develops a more refined awareness of itself and 'becomes an agent of its own' (2010: 161).

As several studies have stressed, this awareness supported by the yoga practice leads practitioners towards a feeling of empowerment, self-confidence and self-transformation (Nevrin 2008; Smith 2004, 2007, 2008; Burger 2006). However, this transformation would not remain in the physical-attitudinal sphere. The intermingled researches of Laura Mandelbaum and Sara Strauss have revealed that nearly two thirds of their respondents considered yoga as a source of discipline and a trigger for a work ethic (2013: 185). Furthermore, Sidnell interprets the daily practice of āsana in Ashtanga Yoga as a form of ethics, in so far as āsanas are not solely bodily techniques but meditative ones (given the precise coordination of breath and the attention required) whose purpose is 'the cultivation of self', through which the individual is stimulated to become a good or a better person (2017: 15-16). The importance of discipline in Ashtanga Yoga had been already stressed by Smith (2008: 140), who emphasised that the practice of asanas inflames in teachers and dedicated practitioners a physical discipline that is comparable to tapas, so that the 'heated effort' of ascetic practice becomes the sweating and bodily heat of modern yoga. Likewise, Lars Jørun Langøien reveals that the practice of Ashtanga Yoga may become 'an embodiment of religio-spiritual practice, which for the dedicated practitioner is an encompassing disciplining of both body and mind' (2012: 27). This inner dimension of yoga has been the subject of investigation by Sarbacker (2014: 20), who notes that many contemporary yoga practitioners adopt contemplative or spiritual practices from Hindu and Buddhist philosophy, and that this mystique and spiritual appeal would be one of the reasons why one "feels great' after a yoga session (2014: 102).

But is this feeling the result of the practice of yoga in itself? Hauser has questioned the role that habitual language used in yoga tutorials has in shaping 'the experience of yoga practitioners, their perspective of the body and its potential for self-development' (2013: 29). Using case studies from Bikram Yoga classes (a 'style' of yoga which required the teachers to follow a specific class script verbatim) and Yoga for Everyone promoted by Kareen Zebroff in Germany, Hauser stresses how 'speech conventions have tremendous influence on how the regular performance of yoga exercises changes the subjective perspective of the body and its potential for self-development' (2013a: 112). This would mean that, whether intended or not, it is suggested to practitioners how they should feel and think about their corporeal self during and after practising yoga. Therefore, one could wonder whether there is a kind of placebo effect in the practice of yoga and whether the expectations of practitioners are such that they necessarily get what they are looking for. ${ }^{4}$

However, not all practitioners engage in yoga with the same intensity, or for the same reasons. For example, Mimi Nichter (2013: 221), in her fieldwork in Mysore, recognises four typologies 
of practitioners: the yoga tourist or 'yoga lites'; the yoga traveller; the yoga practitioner 'going to the source'; and the yoga professional. As part of her research, she also describes the response of the local Indian community, which manifests in 'Indian entrepreneurs and cultural brokers who flourish on the edges of the yoga school and interface with foreign yoga students' (2013: 201), trying to exploit them. This topic demonstrates how ethnographic fieldworks based on direct observation enable researchers to expand the area of interest by bringing to light often overlooked consequences of the spreading of yoga practices and schools - thereby expanding the field of yoga studies.

For this reason, it is not surprising that the modern practitioner has been also analysed as a consumer, and yoga analysed as a product in which branding processes highly develop. In effect, as Anne Koch argues (2013: 245), although the core doctrine of detachment and relaxation in modern yoga can be interpreted as a reaction to our society, the self-enhancement of yoga-body practices does not entail resistance to modern economic systems. Jain (2012c; 2015; see also Jain, Chapter 5 in this volume) examines several yoga brands - IyengarYoga, Siddha Yoga and Anusara Yoga - and demonstrates that they can be contextualised in the social milieu of contemporary consumer culture, being subject to a sequential branding process of selection, introduction, elaboration and fortification (2012c: 4). Since yoga is seen as a method for self-development, it 'can be consumed in combination with other worldviews and practices', making it 'attractive to large target audiences of consumers who do not want to go to an Indian ashram nor seek out a proselytizing guru in order to "do yoga" as it is colloquially put' (2012c: 6). According to Jain, branded yoga products - mats, pants, styles, teachers, services - have to contain the selfdevelopmental needs of the consumers so that they feel personally connected to them. Yoga becomes a tool that enables 'consumers to become better people through physical and psychological transformation' (Jain 2015: 78 (my emphasis)). Offering another layer of analysis of yoga practitioners as consumers, Mandelbaum and Strauss (2013: 182) conducted an internet survey of retreats, vacations and trainings offered to yoga consumers, through which they reveal that the prices of these events transform the practice of yoga into a luxury that creates class distinctions.

A doubt might arise, then, as to whether this " me-oriented" spiritual quest, marked by a discourse of 'nailing' poses and pushing through to practice higher series of āsana practice ${ }^{5}$ can still be considered yoga (Nichter 2013: 221). Indeed, questions about authenticity have been crucial for practitioners and scholars. However, scholars today are unanimous in asserting that it is impossible to draw a line that divides those practices that are legitimate from those that are not (Alter 2008: 47). According to Samuel, those 'syncretic, (post)modern and transnational phenomena that are termed "yoga" today should not be dismissed or condemned simply on account of their dislocation from the perceived tradition' (2008: 178). They should indeed be critically historicised, and all claims of both originality and orthopraxy scrutinised 'so as to understand why the claims are made rather than whether they are true' (Alter 2008: 47). Using such scrutiny, Altglas $(2005,2014)$ claims that transnational Siddha Yoga and Sivananda centres tell us 'more about religious attitudes in western societies today, than about Hinduism itself' (2011: 240) since they underwent a process of westernisation caused by western disciples who adopted and appropriated practices and values as tools to answer 'the urge for self-development characterizing large sections of western societies' (2011: 240).

This westernisation of yoga is not left uncriticised. Jain (2012b: 4) discusses how postural yoga has Hindu opponents because it is perceived as the 'product of a profit-driven market featuring the co-optation and corruption of an otherwise authentic, Hindu system'. However, in the same article she shows that postural yoga also has Christian opponents because it is perceived as too Hindu, hence in conflict with Christian doctrine and therefore an obstacle on the path to salvation. It is the case that movements based on yogic practice have attracted such 
a number of followers as to be considered religious movements. Lola Williamson (2010: ix) explores the experiences, views and lifestyles of people who have been participating in SelfRealization Fellowship, Transcendental Meditation and Siddha Yoga. She analyses how these movements produced a new hybrid form of religion which 'combines aspects of Hinduism with Western values, institutional forms, modes of teaching, and religious sensibilities'. She explores the contours of these movements and their implications for American culture through personal, historical and cultural lenses. Williamson's work provides modern examples that support Jain's claim that the long history of yoga is made of interactions of various traditions and that, therefore, "there is no "legitimate", "authentic", "true", or "original" tradition, only contextualized ideas and practices organized around the term yoga' (2012b). A syncretic perspective through which to interpret contemporary yoga is also supported by Kenneth Liberman (2008), who argues that in modern times, yoga and bhoga (sensual enjoyment) are not easily distinguishable. ${ }^{6}$ The narrative that contemporary practice derives from an original, ancient and pure yoga, he continues, belies the true syncretism of contemporary yoga and limits the exploration of some of the effects that yoga has on practitioners, such as the development of emotional and imaginative poise and existential empowerment (2008: 129-130).

As revealed by Wildcroft's (2020) research, which included ethnographic observations of a yoga subculture in Britain, there are practitioners who actively support the ongoing evolution of the practice by maintaining communities where practitioners from many lineages and none came together.Wildcroft's work stresses that most individuals have found their own way to relate to the post-lineage $\mathrm{e}^{7}$ network in practice, authority and knowledge through a series of revelations and disillusionments, each shared by a few and supported by the many. Disillusionment may be the result of exploited power relationships. This occurs especially when a search for spirituality ends because of misconducts and sexual scandals, as the recent developments of the \#MeToo campaign has shown. Unfortunately, these are not new concerns. In 2001, Sarah Caldwell used a reflexive methodology to dig into and interpret the dimensions of power and uses of sexuality in the religious context of the Siddha Yoga movement in relation to the person of Swami Muktananda. Furthermore, Jain (2012c) has analysed the scandals surrounding the founder of Anusara Yoga.

As this section has shown, there has been an increasing amount of recent scholarship based on data collected through ethnographic work. Nevertheless, attention towards more noninternational scenarios in India remains scarce. Exceptions are the works of Joseph Alter (2008) and RaphaëlVoix (2008), which provide interesting information on the reinterpretation of yoga in contemporary India. In his explanation of the organisation of the yoga śivir (campus), Alter demonstrates that also in India 'yoga becomes a means to develop morals, standards of good character, and civic-mindedness', while the 'performativity of the shivir lends itself very well to advocacy for social and moral reform based on the "virtues" of yama and niyama' (2008: 44). Voix, instead, demonstrates the dangerous results that the new interpretation of yoga can assume. He analyses the case of the Ananda Marg and its reinterpretation and codification of the Yogas ùtra as 'a higher type of spiritual discipline called "extraordinary yoga" (biśesa yoga)', a practice that is kept secret and that can lead the most advanced to 'psychic clash': a state of profound despair which is considered an integral part of the Ananda Marga spiritual path (2008: 17). ${ }^{8}$

More grounded in fields that deal with meditation among 'traditional' orders in South and Southeast Asia are - to mention just a few - the works of Houtman (1990), Cook (2010) Jordt (2007) and Cassaniti (2018), while the works of Mallinson (2005, 2011a, 2012, 2013, 2018) and Lamb $(2005,2012)$ provide original hints about the yoga practice of Vaiṣnava and Nāth sādhus in India. It is noteworthy that although the yoga practice of more traditional India-based ascetics has been described by the aforementioned scholars and finds space among the paragraphs of 
a few others (see, for example, Gross 1992; Hausner 2007; Bouillier 2017), an ethnographic study focused entirely on this issue has never been carried out before. This is quite surprising considering that, probably, yogic techniques developed in ascetic contexts.

\section{Ethnography among sädhus in India}

When I started to work on the yoga practices of ascetics in present-day India for the Hatha Yoga Project in 2015, I was surprised by the paucity of ethnographic works dealing with average ascetics belonging to deep-rooted lineages who learn yoga practices through oral transmission. ${ }^{9}$ The purpose of my ethnographic research was to remedy this lack of information by engaging in fieldwork among sādhus belonging to the main sampradāyas (religious orders) connected with yoga practice, i.e. Nāgā Daśanāmīs, Rāmānandīs, Nāths, Udāsīns and also some vairāgīs from the Rāmānūjī sampradāya. I aimed to reconstruct an emic understanding of yoga and hathayoga among sādhus, and I reported on their present practice through interviews, casual conversations, photos or videos of practitioners. I undertook extensive fieldworks in India in various holy cities, attending religious gatherings in search of ascetic practitioners and moving between āśrams and religious centres to spend time with sädhus and to allow them to know, recognise and trust me and my research.

Compared to the ethnographic studies outlined above, my fieldwork presents two fundamental differences: the difficulty of being a practitioner, and the fact of being a woman. We have seen that in various ethnographic works among yoga practitioners outside of India, scholars were often part of the practice, a practice that involves the intensive participation of women. ${ }^{10}$ In my case, during four fieldworks from October 2015 to March 2019 covering various regions

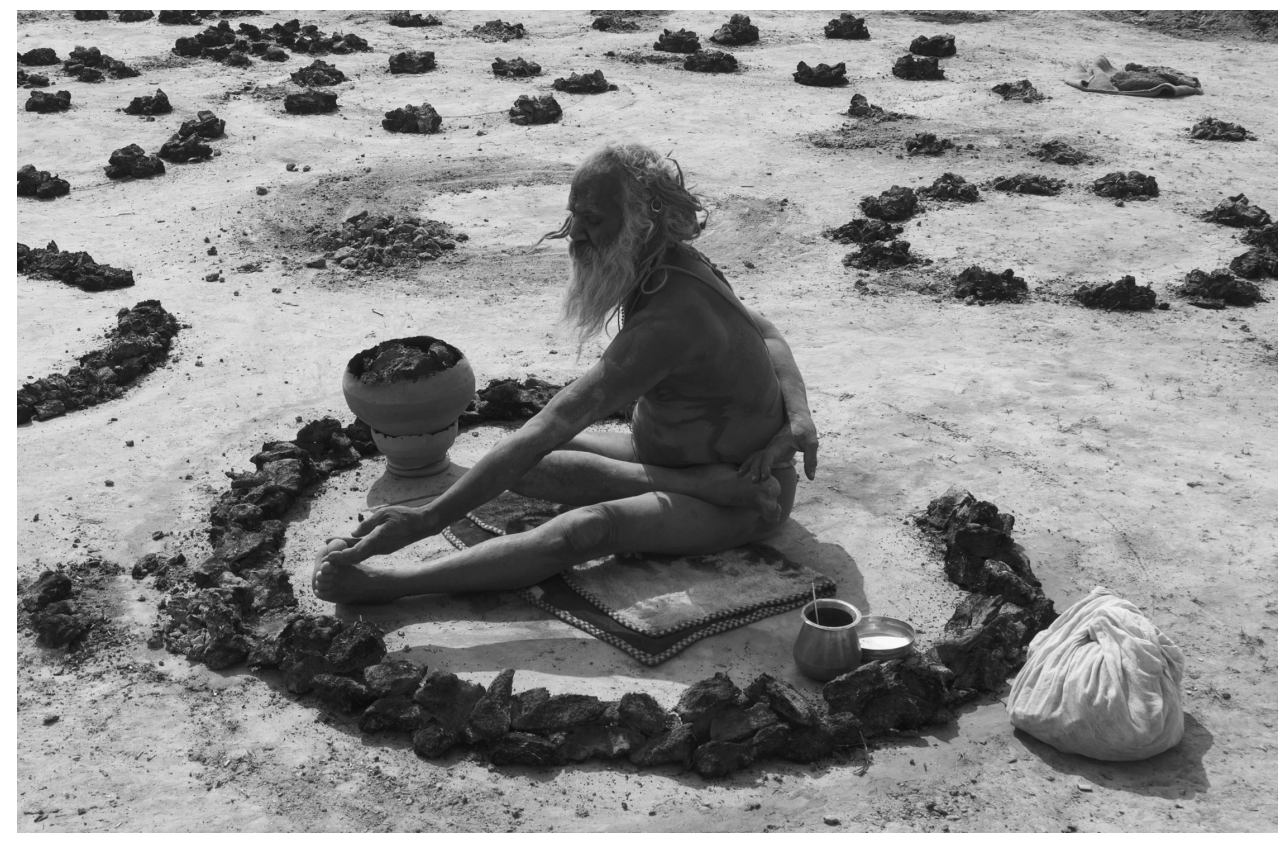

Figure 27.1 Phalahari Baba, a Rāmānandī tyāgì , performs dhūnī tap. Allahabad, February 2019. Credit: Daniela Bevilacqua. 
and religious orders mostly in North India, there were just two female informants. Although it is said that there is not a gender distinction in the sadhu society, in reality it is a male one in which conventional gender roles still operate and in which the female presence is very limited. Together with cultural and traditional discouragement about female asceticism, one strong reason why ascetics prefer to limit the female presence is that brahmacārya (celibacy) is very important. Therefore it is preferable to keep women at a distance or to maintain limited contact with them, and this is quite possible in India because the patriarchal society is such that it is unlikely that unmarried women will go to talk with sādhus or spend time with them. When this happens, specific behaviours are maintained, and I had to learn how to behave properly in front of a sādhu to be considered a respectable woman. However, the fact that I was a foreigner, a researcher and that I can converse in Hindi created that curiosity and respect which helped to break the wall of distrust and suspicion.

The difficulty of being a practitioner in this context stems from the fact that sādhus give proper teachings only to those who are initiated into their orders. ${ }^{11} \mathrm{My}$ decision to not be initiated in any tradition was both ethical and practical: it was awkward for me to take initiation (with the requisite duties and the faith around which such duties revolve) only in order to obtain information about practices, ${ }^{12}$ and I did not consider it appropriate to acquire an esoteric knowledge that was not supposed to be shared with non-initiated audiences. From a practical point of view, to get initiated into a specific order would have meant remaining close to a single guru, at least during the religious festivals, limiting the time spent with sādhus from other sampradāyas.

Ascetics understand yoga as a sädhana (religious discipline), which slowly proceeds towards the development of detachment to realise a communion with God. Therefore, according to many ascetics, since yoga is an inner practice that happens on a level of reality indescribable by words, it cannot be shared, only experienced.

A similar argument is put forth by Cook (2010: 20) in investigating meditation in Thailand. She writes:

the emphasis placed upon the experiential dimension of meditation makes it a particularly thorny challenge for anthropology: in many ways research about meditation is an attempt to 'eff' the ineffable [...] some questions were met with responses such as 'acknowledge' or meditate and you will know. ${ }^{13}$

Additionally, Houtman (1990: 156) declares that he had to work mostly with informants who were "“improvising" meditators' because they were 'the ones most forthcoming in talking of their experiences', while monks replied to him to engage in three months of full-time meditation for twenty hours a day without talking or writing to obtain results. Fortunately, since in my case the research focuses on hathayoga practices (șat karma, āsana, prānāyāma, mudrā, bandha), and since $s \bar{a} d h u s$ do not have particular restrictions in talking about some techniques of the physical part of their yoga sādhana, it was possible to collect data. In the next section, I select a few topics to practically demonstrate how ethnography can provide fundamental hints to inform research into yoga, its history, its practices and further development.

\section{Analysing ethnographic data}

As I have written elsewhere (Bevilacqua 2017), the simple question 'what is hathayoga?' addressed to sädhus allowed me to reconstruct an emic understanding of the meaning of hathayoga. Although the word haț ha has been generally understood as a system of physical techniques (șat karma, àsana, prānāyāma, mudrā, bandha) supplementary to yoga, in my conversation with ascetics 
four different meanings were attributed to the label: hathayoga was strictly connected with tapasya, i.e. it was the mental determination that helps in performing and keeping austerities; hathayoga was linked to the esoteric meaning of the union of ha- the sun and -tha the moon, intended as the union of $i d \bar{a}$ and pingala nād $\bar{\imath}$ in the sușumn $\bar{a}$; hathayoga was connected to practices for controlling and suppressing prāna; hathayoga was the practice of kriyās, especially inner, difficult kriyās. I was able to verify that although these various meanings are scattered in textual sources belonging to different religious contexts, these texts are, nevertheless, not mentioned by ascetics. Therefore, confronting ethnographic evidences with textual sources, I demonstrated that the hathayoga tradition was not a monolithic one but was connected to various contexts and developed probably from the teachings of various gurus. Such gurus elaborated, shared and spread practices that could be universally useful for individuals on the path of yoga sädhana. However, the data also demonstrates that sādhus do not use Sanskrit texts systematically. In effect, in the ascetic context the main source of knowledge is the teaching of the guru. These teachings are secret and are the key for getting the ras, juice, of the practice. They can be hidden in texts, but only the guru can explain them; therefore sādhus consider texts as conveyors of a knowledge that everybody can access, but it is a general knowledge. I met very few ascetics who had read books about yoga. Sometimes they can recite ślokas (verses or lines), but the origin of the source is not clear to them.

This ethnographic data encouraged an enquiry into the role of medieval hathayoga manuscripts and their audience. Taking as a starting point Birch's argument that the late literature on hathayoga should be divided in the two etic categories of 'extended works' and 'compendia', I suggest a third category of vernacular texts - unfortunately largely unstudied. Prescriptive texts in vernacular languages were probably produced inside sampradāyas, circulating therefore in the sampradāyik milieu for the individual practice of its ascetics. However, as an article by Birch (forthcoming) demonstrates, in texts such as the Jogapradīpakā, the word hathayoga is not used. Larger collections in Sanskrit were probably written by Brahmin followers of particular gurus, 'working' under specific patrons to promote yoga teachings (see, for example, Mallinson 2019). It is likely that such texts had a purpose similar to that of yoga books today: to attract people and their economic support with practices that could lead to dhyanna yoga. Probably because they were looking at a wider audience, these Sanskrit texts leave aside austerities, i.e. tapasyā, properly practised only by ascetics.

Ethnographic data on the ascetic practice of āsanas also provides interesting information. Often, different āsanas or kriyass are learned from different $s \bar{a} d h u s$, who are expert in specific practices, during pilgrimages or during religious gatherings. Questioning sādhus about āsanas revealed that there are two ideas of àsanas in the ascetic milieu. On the one hand, there are àsanas used as stable, seated positions for practicing dhyāna, in particular sukhāsana, siddhāsana and padmāsana. Then, there are those temporary ăsanas whose purpose is to keep the body healthy by preventing diseases, and to make it sthir, stable, consequently to stabilise the mind to facilitate meditation. The interviews collected show that sädhus focus on one asana at time and only when this is perfected do they start to practise another one. Interestingly, sharing this information with Jason Birch, we were surprised to recognise a similar attitude in the Jogapradīpyakā, probably written by a Rāmānandī sădhu. As Birch related to me in a personal communication, the Jogapradīpyakā contains similar recommendations about the practice of assanas: for example, it suggests that Paścimotānāsana (Jogapradīpyakā 70-78), requires a special preparatory diet, is practised for a period of 168 days and is held continuously for the last eighty-four days of this period (see also Birch and Hargreaves forthcoming). In contemporary practice, when temporary āsanas became siddh (perfected/accomplished), sādhus stop practicing them systematically unless they need to, i.e. to alleviate physical problems or to maintain their physical shape, but not more than few minutes a 
day. Despite this temporary use, āsanas are an initial fundamental step for meditative practice: to practise one assana for a long time increases the perseverance and the intention of the practitioner, so that he will be able to use the same persistence to accomplish and follow religious aims.

This attitude of ascetics towards āsanas could be 'captured' through the ethnographic method. Furthermore, it was useful to understand some contents of the Jogapradīpaka and to relate present with past traditions. It would be interesting to compare sädhus' descriptions of theories and practices with the understanding that modern practitioners have. While in the first case we have knowledge - whose origin is probably lost in time - that primarily derives from an oral transmission strictly connected to the presence of a guru and given only if the disciple is considered apt, in the second case we may have 'spiritual wanderers', empowered practitioners who may form their 'own opinion cognitively by reading and attending lectures, and through (embodied) experience of spiritual methods' (Koch 2013: 247). Similar discussions demonstrate how direct conversation with ascetic practitioners can lead to observations that help us in outlining the historical development of physical yogic practices, also creating a comparison with modern yoga, its practices and its transmission.

\section{Challenges and conclusions}

This chapter demonstrates how scholars are becoming interested in understanding the practices, aims, results and environments that influence practitioners who belong to one of the various postural yogic or meditative movements spread all over the world. To fully understand these new topics, scholars often turn to ethnographic methods. Considering, in fact, that yoga is an experiential discipline (as sädhana and as physical training), ethnography provides useful tools (especially participant observation that in some cases becomes co-participation) to dig into and interpret diverse nuances. However, the researcher and the reader should be aware of the challenges and the ambiguities inherent to this approach. Hammersley has argued that 'the idea that ethnographic accounts are simply descriptions of reality "as it is" is misleading' (1990: 607), because for any phenomenon 'there is an infinity of factors that played a role in its production', and we, as scholars, 'select from that range those factors that are relevant to the purposes that our explanation is intended to serve'. Therefore, one should take into consideration that the description and the explanation of data is influenced by the figure of the researcher and his/her value.

In the field of yoga studies, wherein many researchers are also privately involved in the practice, there is also the risk of what Hammersley defines as 'the potential to turn ethnographic description into an ideological device in which an account shaped by particular values is presented as if it were the only description or explanation possible' (1990: 609). That is why we should not only attempt to be as reflexive and honest as possible in the production of our results, but also try 'to understand the context and form of practice', of the 'many different ways in which yoga can be performed and taught' (Alter 2008: 47). This means confronting ethnographic data with other sources because, as Alter suggests,

it is also important to understand the way in which yoga, as represented in the classical and medieval literature - which reveals differences and delineations in the form, structure, and meaning of practice - tends to get blurred together with modern and postmodern formulations.

As my ethnographic work among ascetics demonstrates, to maintain a synchronic and diachronic approach while analysing the studied realities is useful and fruitful to understand present situations and, through them, to interpret past contexts. 
Given the fact that the topics and issues of investigation will most likely increase in the future of yoga studies, we can expect further ethnographic research among the numerous Indian religious orders and transnational yoga groups. Such systematic multidisciplinary research enquiry will overcome the challenges and problems that accompany the ethnographic method, helping to broadly reconstruct the history and the development of yogas in India and abroad.

\section{Glossary}

bandha, lock

kriyā, action

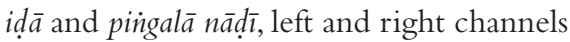

kartik vrat, vows during the Indian month of Kartik.

prāna, breath

paramparā, traditional lineage

$p \bar{u} j \bar{a}$, worship

sādhana, religious discipline

sadhu, holy man

sampradāya, religious order

tapas, inner spiritual fire

tapasyā, austerity

suṣumṇa nāḍ̄ , central channel

\section{Notes}

1 This chapter was financially supported by the European Union's Horizon 2020 research and innovation programme under grant agreement No. 647963 (Hațha Yoga Project).

2 For an overview of yoga scholarship undertaken by indologists and historians of religion, see Hauser (2013b: 11-16) and Newcombe (2009).

3 Wildcroft (2020) defines this as 'co-practice.'

4 On the other side, Pagis' ethnographic data on meditation illustrates how 'despite the absence of direct verbal communication, the practice of meditation still holds important intersubjective dimensions'. He suggests that 'covert mechanisms of silent intersubjectivity play an important role in everyday social life and require further ethnographic attention' (2010).

5 According to Schnäbele (2013: 221), the flow of yoga students to Mysore is increasing, but the reasons why they are going has changed over the decades: in the 1960s and 1970s those who went to study with Pattabhi Jois demonstrated a more devotional attitude, while today's younger students have a more 'me-oriented' attitude.

6 Yoga and bhoga have been sharply distinguished in history. Bhoga, understood as the experience of supernatural pleasures, was the aim of Śaiva groups who were followers of the Mantramārga (Sanderson 1988: 667). Mallinson notes that with the development of hathayoga systems the main tendency was to preserve the seeker of liberation rather than the seeker of enjoyment. Therefore, although hathayoga incorporated various traditions that can refer to the Mantramārga, it did away with 'their complex and exclusive bhoga-oriented systems' (2011b). The Haṭhapradīpikā, for example, claims that bhoga (enjoyments) are the greatest of all impediments for yoga.

7 Post-lineage yoga consists of 'a re-evaluation of the authority to determine practice, and a privileging of peer networks over pedagogical hierarchies, or saṃghas (communities) over guru-śisya (teacher-adept) relationships' (Wildcroft 2020).

8 As Voix mentions (2008: 17), a theoretically similar technique of shock seems to be used in other contemporary religious groups inspired by tantrism, as described by Sarah Caldwell concerning alleged sexual abuses involving Swami Muktananda and his Siddha Yoga (2001: 9).

9 If we look instead at works which take into consideration international or modern sādhus, the production is wide and detailed. See, for example: the work of Strauss (2005) on Swami Sivananda; the works of 
Persson $(2007 ; 2010)$ and Pankhania (2008) on Swami Satyananda;Aveling (1994) on Swami Satyananda and Osho; and the work of Khalikova (2017) and Longkumer (2018) on Baba Ramdev.

10 A 2012 survey by Yoga Journal found that of the 20.4 million people who practise yoga in the United States, only 18 percent of them are men. (www.yogajournal.com/blog/new-study-finds-20-millionyogis-u-s. Accessed April 2019).

11 In my case, I could not spend time on personal practices, since the results would not have been of any interest for my research, and given the time needed to attain a sufficient level to be shared or compared with that of sādhus, the five years of the project would have not been enough.

12 Joanna Cook (2010) became a Buddhist nun committed to ordination and meditation. However, the members of the monastery were aware that her ordination would be limited to one year in which she would undertake anthropological research. Another case is that of Ingrid Jordt (2007), who also became a Buddhist nun for several years, focusing her attention on vipassana as a diplomatic link between Burma and the rest of the world.

13 This practical approach has been testified also by scholars working with the founders of modern transnational yoga. For example, Smith reports that Pattabhi Jois used to claim: 'Ninety-nine percent practice, one percent theory [...] practice and all is coming' (2008: 153).

\section{Bibliography}

Alter, J. 2004. Yoga in Modern India: The Body Between Science and Philosophy. Princeton: Princeton University Press.

Alter, J. 2008. 'Yoga Shivir: Performativity and the Study of Modern Yoga', in Singleton, M. and Byrne, J. (eds), Yoga in the Modern World: Contemporary Perspectives, 36-48. London and New York: Routledge Hindu Studies Series.

Altglas,V. 2005. Le Nouvel Hindonisme Occidental. Paris: Éditions du CNRS.

Altglas, V. 2011. 'Yoga and Kabbalah as World Religions? A Comparative Perspective on Globalization of Religious Resources,' in Huss, B. B. (ed), Kabbalah and Contemporary Spiritual Revival, 233-50. Beer Sheva: Ben-Gurion University of the Negev Press.

Altglas, V. 2014. From Yoga to Kabbalah: Religious Exoticism and the Logics of Bricolage. Oxford and New York: Oxford University Press.

Atkinson P., and Hammersley, M. 1994. 'Ethnography and Participant Observation', in Denzin, N. K. and Lincoln,Y. S. (eds), Handbook of Qualitative Research, 248-261. Newbury Park: Sage.

Aveling, H. 1994. The Laughing Swamis: Australian Sannyasin Disciples of Swami Satyananda and Osho Rajneesh. Varanasi: Motilal Banarsidass Publisher.

Bevilacqua, D. 2017. 'Let the Sādhus Talk. Ascetic Understanding of Hațha Yoga and Yogäsanas'. Religions of South Asia 11(2): 182-206.

Birch, J. 2020. 'Hathayoga's Floruit on the Eve of Colonialism', in Goodall, D., Hatley, S., Isaacson, H. and Raman, S. (eds), Śaivism and the Tantric Traditions: Essays in Honour of Alexis G. J. S. Sanderson. Leiden: Brill.

Birch, J. and Hargreaves, J. (forthcoming). 'Distinct Regional Collections of $\bar{A}$ sanas in Eighteenth and Nineteenth-century India'. Journal of Yoga Studies.

Bouillier,V. 2017. Monastic Wanderers, Näth Yogi Ascetics in Modern South Asia. New Delhi: Manohar.

Broo, M. 2012. 'Yoga Practices as Identity Capital, Preliminary notes from Turku, Finland'. Scripta Instituti Donneriani Aboensis 24: 24-34. https://doi.org/10.30674/scripta.67406

Burger, M. 2006. 'What Price Salvation? The Exchange of Salvation Goods between India and the West'. Social Compass 53: 81-95.

Byrne, J. and Singleton, M. (eds) 2008. Yoga in the Modern World: Contemporary Perspectives. New York: Routledge Hindu Studies Series.

Caldwell, S. 2001. 'The Heart of the Secret: A Personal and Scholarly Encounter with Shakta Tantrism in Siddha Yoga'. Nova Religio 5(1): 9-51.

Cassaniti, J. 2015. Living Buddhism: Mind, Self, and Emotion in a Thai Community. Ithaca: Cornell University Press.

Cassaniti, J. 2018. Remembering the Present, Mindfulness in Buddhist Asia. Ithaca, NY, USA: Cornell University Press.

Cook, J. 2010. Meditation in Modern Buddhism: Renunciation and Change in Thai Monastic Life. Cambridge: Cambridge University Press. 


\section{Daniela Bevilacqua}

De Michelis, E. 2004. A History of Modern Yoga. London: Continuum.

Goldberg, E. and Singleton, M. (eds) 2013. Gurus of Modern Yoga. Oxford University Press.

Gross, L. R. 1992. The Sadhus of India, A Study of Hindu Asceticism. New Delhi: Rawal Publications.

Hammersley, M. 1990. 'What's Wrong with Ethnography? The Myth of Theoretical Description'. Sociology 24(4): 597-615.

Hasselle-Newcombe, S. 2005. 'Spirituality and "Mystical Religion" in Contemporary Society: A Case Study of British Practitioners of the Iyengar Method of Yoga'. Journal of Contemporary Religion 20(3): 305-321.

Hauser, B. 2013a. 'Touching the Limits, Assessing Pain: On Language Performativity, Health, and WellBeing in Yoga Classes', in Hauser, B. (ed), Yoga Traveling, Bodily Practice in Transcultural Perspective, 109-134. Heidelberg: Springer.

Hauser, B. 2013b. Yoga Traveling, Bodily Practice in Transcultural Perspective. Heidelberg: Springer.

Hausner, S. 2007. Wandering with Sadhus: Ascetics in the Hindu Himalayas. Bloomington: Indiana University Press.

Houtman, G. 1990. Traditions of Buddhist Practice in Burma. PhD thesis, SOAS, University of London.

Jain, A. 2012a. 'The Dual-Ideal of the Ascetic and Healthy Body: The Jain Terāpanth and Modern Yoga in the Context of Late Capitalism'. Nova Religio 15(3): 29-50.

Jain, A. 2012b. 'The Malleability of Yoga: A Response to Christian and Hindu Opponents of the Popularization of Yoga'. Journal of Hindu-Christian Studies 25: 3-10.

Jain, A. 2012c. 'Branding Yoga. The Cases of Iyengar Yoga, Siddha Yoga and Anusara Yoga'. Approaching Religion 2(2): 3-17.

Jain, A. 2014. Selling Yoga: From Counter-Culture to Pop Culture. New York: Oxford University Press.

Jordt, I. 2007. Burma's Mass Lay Meditation Movement: Buddhism and the Cultural Construction of Power. Ohio University Press.

Khalikova,V. R. 2017. 'The Ayurveda of Baba Ramdev: Biomoral Consumerism, National Duty and the Biopolitics of "Homegrown" Medicine in India'. South Asia: Journal of South Asian Studies 40(1): 105-122.

Knut, A. J. 2005. Theory and Practice of Yoga: Essays in Honour of Gerald James Larson. Leiden: Brill.

Koch,A. 2013. 'Yoga as a Production Site of Social and Human Capital: Transcultural Flows from a Cultural Economic Perspective', in Hauser, B. (ed), Yoga Traveling, Bodily Practice in Transcultural Perspective, 225248. Heidelberg: Springer.

Lamb, R. 2005. 'Rāja Yoga, Asceticism, and the Rāmānanda Sampradāy', in Jacobsen, K. A. (ed), Theory and Practice of Yoga: Essays in Honour of Gerald James Larson, 317-331. Leiden: Brill.

Lamb, R. 2012. 'Yogic Powers and the Rāmānanda Sampradāy', in Jacobsen, K. A. (ed), Yoga Power. Extraordinary Capacities Attained Through Meditation and Concentration, 427-457. Leiden: Brill.

Langøien, L. J. 2012. 'Yoga, Change and Embodied Enlightenment'. Approaching Religion 2(2): 27-37.

Liberman, K. 2008. 'The Reflexivity of the Authenticity of Hațha Yoga', in Singleton, M. and Byrne, J. (eds), Yoga in the Modern World: Contemporary Perspectives, 100-116. New York: Routledge Hindu Studies Series.

Longkumer, A. 2018. “Nagas Can't Sit Lotus Style”: Baba Ramdev, Patanjali, and Neo-Hindutva'. Contemporary South Asia 26(4): 400-420.

Mallinson, J. 2005. 'Rāmānandī Tyāgīs and Haṭa Yoga'. Journal of Vaishnava Studies 14(1): 107-121.

Mallinson, J. 2011a. 'Nāth Sampradāya', in Jacobsen, K.A., Basu, H., Malinar,A. and Narayanan,V. (eds), Brill Encyclopedia of Hinduism Vol. 3, 407-428. Leiden: Brill

Mallinson, J. 2011b. 'Hațha Yoga', in Jacobsen, K. A., Basu, H., Malinar, A. and Narayanan, V. (eds), Brill Encyclopedia of Hinduism Vol. 3, 770-781. Leiden: Brill.

Mallinson, J. 2012. 'Yoga and Yogis'. Nāmarūpa 3(15): 2-27.

Mallinson, J. 2013. 'Yogic Identities: Tradition and Transformation'. Smithsonian Institute Research Online, https://eprints.soas.ac.uk/17966/. Accessed 12 March 2020.

Mallinson, J. 2018. 'Yoga and Sex: What is the Purpose of Vajrolīmudrā', in Baier, K., Maas, P. A. and Preisendanz, K. (eds), Yoga in Transformation, Historical and Contemporary Perspectives, 181-222. Vienna: V\&R Unipress.

Mallinson, J. 2019. 'Kālavañcana in the Kokan: How a Vajrayāna Haṭhayoga Tradition Cheated Buddhism's Death in India'. Religions 10(4): 273. https://doi.org/10.3390/rel10040273.

Marcus, E. G. 1995. 'Ethnography in/of the World System: The Emergence of Multi-Sited Ethnography'. Annual Review of Anthropology 24: 95-117.

Nevrin, K. 2008. 'Empowerment and Using the Body in Modern Postural Yoga', in Singleton, M. and Byrne, J. (eds), Yoga in the Modern World: Contemporary Perspectives, 119-139. New York: Routledge Hindu Studies Series. 
Newcombe, S. 2005. 'Spirituality and "Mystical Religion" in Contemporary Society: A Case Study of British Practitioners of the Iyengar Method of Yoga'. Journal of Contemporary Religion 20(3): 305-321.

Newcombe, S. 2009. 'The Development of Modern Yoga: A Survey of the Field'. Religion Compass 3(6): 986-1002.

Newcombe, S. 2018. 'Spaces of Yoga: Towards a Non-Essentialist Understanding of Yoga', in Baier, K., Mass, P. A. and Preisendanz, K. (eds), Yoga in Transformation: Historical and Contemporary Perspectives, 551573.Vienna: Vienna University Press.

Newcombe, S. 2019. Yoga in Britain. Stretching Spirituality and Educating Yoga. Sheffield: Equinox Publishing.

Mandelbaum, L., and Strauss, S. 2013. 'Consuming Yoga, Conserving the Environment: Transcultural Discourses on Sustainable Living', in Hauser, B. (ed), Yoga Traveling, Bodily Practice in Transcultural Perspective, 175-200. Heidelberg: Springer.

Nichter, M. 2013. 'The Social Life of Yoga: Exploring Transcultural Flows in India', in Hauser, B. (ed), Yoga Traveling, Bodily Practice in Transcultural Perspective, 201-223. Heidelberg: Springer.

Pagis, M. 2010. 'Producing Intersubjectivity in Silence: An Ethnographic Study of Meditation Practice'. Ethnography 11(2): 309-328.

Pankhania, J. 2008. Encountering Satyananda Yoga in Australia and India: Reflections of a Complex, Postcolonial, Gendered Subject. PhD dissertation, University of Western Sydney. Centre for Cultural Research.

Pearson, J. 2001. “'Going Native in Reverse”: The Insider as Researcher in British Wicca', Nova Religio 5(1): 52-63

Persson, A 2007. 'Intimate Immensity: Phenomenology of Place and Space in an Australian Yoga Community'. American Ethnologist 34(1): 44-56.

Persson, A 2010. 'Embodied Worlds: A Semiotic Phenomenology of Satyananda Yoga'. Journal of the Royal Anthropological Institute NS 16(4): 797-815.

Pintchman, T. 2005. 'Raising Krishna with Love: Maternal Devotion as a Form of Yoga in a Women's Ritual Tradition', in Jacobsen, K. A. (ed), Yoga Power. Extraordinary Capacities Attained Through Meditation and Concentration, 351-362. Leiden: Brill.

Pole, C. and Morrison, M. 2003. Ethnography for Education. London: Open University Press, McGraw-Hill Education.

Samuel, G. 2008. The Origins of Yoga and Tantra. Cambridge: Cambridge University Press.

Sanderson, A. 1988. 'Śaivism and the Tantric Traditions', in Sutherland, S., Houlden, L., Clarke, P. and Hardy, F. (eds), The World's Religions, 660-704. London: Routledge and Kegan Paul.

Sarbacker, S. R. 2008. 'The Numinous and Cessative in Modern Yoga', in Singleton, M. and Byrne, J. (eds), Yoga in the Modern World: Contemporary Perspectives, 161-183. London: Routledge.

Sarbacker, S. R. 2014. 'Reclaiming the Spirit through the Body: The Nascent Spirituality of Modern Postural Yoga'. Entangled Religions Interdisciplinary Journal for the Study of Religious Contact and Transfer, 1: 95-114.

Schnäbele,V. 2010. Yoga in Modern Society. Hamburg: Verlag Dr. Kovac.

Schnäbele, V. 2013. 'The Useful Body: The Yogic Answer to Appearance Management in the PostFordist Workplace', in Hauser, B. (ed), Yoga Traveling, Bodily Practice in Transcultural Perspective, 135-154. Heidelberg: Springer.

Sidnell, J. 2017. 'Ethical Practice and Techniques of the Self at a Yoga School'. Anthropology Today 33(4): 13-17.

Singleton, M. and Byrne, J. (eds) 2008. Yoga in the Modern World: Contemporary Perspectives. New York: Routledge Hindu Studies Series.

Sjoman, N. E. (1999). The Yoga Tradition of the Mysore Palace. New Delhi: Abhinav Publications.

Smith, B. R. 2004. 'Adjusting the Quotidian: Ashtanga Yoga as Everyday Practice'. in The Online Proceedings from Everyday Transformations; The 2004 Annual Conference of the Cultural Studies Association of Australasia. https://openresearch-repository.anu.edu.au/handle/1885/80667. Accessed 12 March 2020.

Smith, B. R. 2007. 'Body, Mind and Spirit? Towards an Analysis of the Practice of Yoga'. Body \& Society 13(2): 25-46.

Smith, B. R. 2008. “With Heat Even Iron Will Bend”: Discipline and Authority in Ashtanga Yoga', in Singleton, M. and Byrne, J. (eds), Yoga in the Modern World: Contemporary Perspectives, 140-160. London: Routledge.

Strauss, S. 2000. 'Locating Yoga: Ethnography and Transnational Practice', in Amit,V. (ed), Constructing the Field, 162-194. New York: Routledge.

Strauss, S. 2002. “'Adapt, Adjust, Accommodate”: The Production ofYoga in a Transnational World'. History and Anthropology 13(3): 231-251. 


\section{Daniela Bevilacqua}

Strauss, S. 2005. Positioning Yoga, Balancing Acts Across Cultures. Berg: Berg Publishers.

Van Maanen, J. 1996. 'Ethnography', in Kuper, A. and Kuper, J. (eds), The Social Science Encyclopedia, 263265. London: Routledge.

Voix, R. 2008. 'Denied Violence, Glorified Fighting: Spiritual Discipline and Controversy in Ananda Marga'. Nova Religio: The Journal of Alternative and Emergent Religions, 12(1): 3-25.

Wildcroft, T. 2020. Post-lineage Yoga: From Guru to \#MeToo. Sheffield: Equinox Publishing.

Williamson L. 2010. Transcendent in America: Hindu-Inspired Meditation Movements as New Religion. New York: New York University Press. 